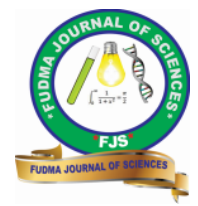

FUDMA Journal of Sciences (FJS)

ISSN online: $2616-1370$

ISSN print: 2645 - 2944

Vol. 4 No. 3, September, 2020, pp $457-463$

DOI: https://doi.org/10.33003/fjs-2020-0403-413

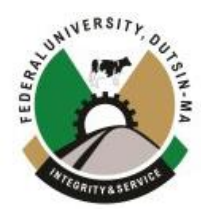

\title{
DETERMINATION OF AFLATOXIN M1 IN RAW MILK PRODUCE AT YOBE STATE UNIVERSITY FARM DAMATURU, NIGERIA
}

\author{
${ }^{* 1}$ Gide S., ${ }^{1}$ Mohammed B., ${ }^{1}$ Galal G. H, ${ }^{1}$ Iliyah A. A., ${ }^{1}$ Mabu I. M, ${ }^{1}$ Lawan M. S., ${ }^{1}$ Muhammad Y. and ${ }^{2}$ Sheriff W., \\ ${ }^{1}$ Desert Research and Monitoring Control Centre, Yobe State University, Damaturu \\ ${ }^{2}$ Department of Microbiology, Yobe State University, Damaturu.
}

Corresponding Author's email: gidesule@ysu.edu

\begin{abstract}
The study was carried out to determine the contamination of aflatoxin_M1 (AFM1) in samples ( $n=66)$ of raw milk, from three distinctive animal species (cow, $n=30$; goat, $n=20$; sheep, $n=16$ ) at Yobe State University farm Damaturu in 2018. The analytical strategy utilized was high-performance liquid chromatography (HPLC). Immunoaffinity columns were used to achieve clean-up step during HPLC and fluorometric determination. The outcomes demonstrated that 36 (54.54\%) samples out of the 66 samples are debased with AFM1. The sullying rates of AFM1 in dairy animals, goat milk and sheep milk were $80.0 \%, 25.0 \%$ and $46.75 \%$ respectively. The mean concentration for the cow, goat and sheep milk was $0.1333 \mu \mathrm{g} / \mathrm{l}, 0.0462 \mu \mathrm{g} / 1$ and $0.0519 \mu \mathrm{g} / 1$ respectively. The general mean convergence of AFM1 levels for positive samples from the three distinctive species was $0.0727 \mu \mathrm{g} / \mathrm{l}$ and there was no huge contrast $(\mathrm{p}=0.3624)$ in fixation levels between the three species. The estimated intake (EDI) of AFM1 from consumption of cow milk products by teachers and the students was $0.00158 \mathrm{~g} / \mathrm{kg}$ b.w/day based on one-day recall methods, while hazard index was recorded to be $1.58 \times 10-4$. The high levels of AFM1 concentration recorded in this study is an indication of contamination by the fungus during storage of feeds, this may have negative effects on the human and animal's health since it's proven to be carcinogenic, causes growth impairment and immune suppression. Measures should be enforced on the storage of feeds which will consequently decrease the odds of aflatoxin in milk of the animals.
\end{abstract}

Keywords: Aflatoxin, raw milk, cow, sheep, goat, HPLC.

\section{INTRODUCTION}

Mycotoxin signifies "poison from fungi", however, not all harmful compounds produced by the fungus is viewed as mycotoxins (Hussain, 2009). Mycotoxins are secondary metabolites, basically produced by filamentous fungi, for example, Aspergillus flavus, $A$. parasiticus and $A$. nomius that possess a genuine risk for humans and animals (JECFA, 2001). In domestic animals such as cows, ingested AFB1, usually metabolize into a harmful carcinogenic substance which is released through the milk (Bellio et al., 2016). These molds affect a wide scope of horticultural items, such as maize, millets and groundnuts, both in the pre-harvest and postharvest seasons (Sarimehmetoglu et al., 2004). Most mycotoxins are found in grain, typically developed in a dry season condition. Meanwhile, aflatoxins are found in corn and cottonseed, and uncommon in soya beans or distiller's grain. Shelled nut items might be polluted with aflatoxins and bring about toxin in milk items-Additionally, climate changes and poor agribusiness practices may affect the expansion levels of Aflatoxin M1 (AFM1) in dairy products as well as AB1 in food products (Mulunda et al., 2013).

\section{The Chemistry of AFB1 and AFM1}

AFM1, the 4-hydroxylated metabolite of aflatoxin B1 (AFB1) is found in animals, humans bosom milk as well as dairy products (ICRC, 1993). The presence of AFM1 in milk is considered as a potential hazard for human wellbeing due to its cancer-causing nature. (Mulunda et al., 2013). It was first set for research on malignancy (IARC) as group $2 \mathrm{~B}$ agent cancer-causing to people (IARC) which revealed the genotoxicity and cytotoxicity of AFM1 (Caloni et al., 2006), the poison is currently been delegated as group 1 human cancer-causing agent (IARC).
In the year 2004, Martins and Martins reported that around 1-2\% of AFB1 in animal feed is changed to AFM1 in milk with differences from one to another, and over time from one milking to the next. Additionally, it was revealed from the research that admission of AFB1 correspond to AFM1 value in the milk when AFB1 is halted, AFM1 concentration diminishes to an imperceptible level after 3 days. AFB1 in the feed to AFM1 in the milk are highly correlated, a mean carry-over rate at oral administration of feeds containing the toxins after a week appears to increase exponentially. (Shlosberg et al.,2013). The presence of AFM1 in milk has been determined to be within 15 minutes to 60 minutes after utilization and come back to baseline within two to three days after removal from diets (Henry et al., 2001). Studies on AFM1 metabolism have demonstrated that the rate between the measure of AFB1 ingested by dairy animals and the amount discharged in milk is generally 0.2 to $4 \%$ (Henry et al., 2001, Sassahara et al., 2005). It takes 72-144 hours of the consistent day by day ingestion of aflatoxin B1 before unfaltering state discharge of AFM1 in milk can be accomplished (Wagacha and Muthomi,2008).

\section{AFB1 and AFM1 Standard Limits}

Standard limits tolerated worldwide on AFs vary between $10-20 \mathrm{ppb}$ for AFB1 and $0.05 \mathrm{ppb}$ for AFM1 in Europe and South Africa and $0.5 \mathrm{ppb}$ in the United States (Whitlow et al., 2010). Research has shown that concentrations of $20 \mathrm{ppb}$ of AFB1 in the complete blended proportion of a lactating dairy steer could result in AFM1 levels in milk underneath the FDA set up a limit of $0.5 \mathrm{ppb}$. European Union and a few different nations, for example, South Africa have set up a worthy degree of AFM1 in milk and milk 
products at $0.05 \mathrm{ppb}$ (Henry et al., 2001, Whitlow et al., 2010). The examination of the sum 126 test of raw milk, pasteurized milk, and powdered milk demonstrated that $80 \%$ of the test was contaminated with various levels of AFM1 ranging from $0.020 \mu \mathrm{g} / \mathrm{l}$ to $0.765 \mu \mathrm{g} / \mathrm{l}$. The AFM1 contaminated samples exceed the US, Syrian, and EU satisfactory cut-off points with $22 \%, 38 \%$, and $52 \%$ respectively. Most developing countries in Africa have not yet set bearable points of confinement on feed contamination levels of AFs as well as AFM1 in milk. Mulunda et al. (2013) stated that very little work has been done with regards to AFM1 the world. The information in Table 1 demonstrated that only a few African nations apart from South Africa (Dutton et al., 2012), Egypt (Motawee et al., 2009) and Morocco (Zinedine et al., 2006) were engaged with the overview for AFM1.

Table 1 Survey of AFM 1 in developing countries

\begin{tabular}{lllll}
\hline Country & Sample size & Method of detection & Positive (\%) & Ranges $(\boldsymbol{\mu} / \mathbf{L})$ \\
\hline Egypt & 175 & ELISA & $86(49)$ & $0.01-0.250$ \\
Libya & 49 & ELISA & $35(71)$ & $0.03-3.13$ \\
South Africa & 90 & ELISA/IAC/HPLC & $85(94.5)$ & $0.02-1.50$ \\
Morocco & 54 & IAC/HPLC & $48(88.8)$ & $0.001-0.0117$
\end{tabular}

Therefore, the present study aimed to access the level of AFM1 in

The information demonstrated that the review in African nations has a large amount of contamination $(0.05 \mu / 1>)$ in many milk tests analyzed.

Multiple factors determine the contamination of agricultural commodities with mycotoxins, probably the two most important environmental components favouring mold growth and $\mathrm{AF}$ production are hot and humid conditions. The climate change plays a major role in production of aflatoxin from Aspergillus in food crop. (Magan et al., 2011). The temperature interacts with moisture content $\left(\mathrm{a}_{\mathrm{w}}\right)$ and influences the ratio of regulatory genes in A. flavus, which directly proportional to the production of AFB1 (SchmidtHeydt et al., 2010). Increasing temperature to $37^{\circ} \mathrm{C}$ and water stress significantly reduces the production of AFB1 produced, despite the growth of A. flavus under these conditions. According Gallo et al (2016), fungal biomass and AFB1 production were reported to be highest at $28^{\circ} \mathrm{C}$ and $0.96 \mathrm{a}_{\mathrm{w}}$, while no fungal growth or AFB1 production was seen at $20^{\circ} \mathrm{C}$ with value of $0.90 \mathrm{a}$ aw and $0.93 \mathrm{a}$.

The ecological condition in term of humidity and temperature of an environment are factors that could favours the growth molds that may affect carbohydrate-rich cereals such as rice straws, sorghum stalks, corn stalks (at curing stage), when stored poorly and serves as feeds for livestock, thus, AFB1 contamination in the cereals byproducts, then it's carryover in livestock products, such as meat, egg, and milk, thereby compromising the safety of public and animal health. milk produced by three different species of animals and to evaluate the human risk associated with it.

\section{MATERIALS AND METHODS}

\section{Chemical and reagents}

Standard solution of AFM1 (Sigma Aldrich, Steinheim, Germany) was used for the analysis. A day by day working arrangements were set up in acetonitrile/water of $0.004 \mu \mathrm{g} / \mathrm{ml}(25 / 75 \mathrm{v} / \mathrm{v})$ were utilized to spike the samples as indicated by Cammilleri et al (2018).

Deionized water was purchased (Milli Q, Millipore, and Bedford, MA, USA). The Acetonitrile (ACN) and methanol used in the research are specific for HPLC, were obtained from BDH (British drug house).

\section{Sample collection}

A total of 66 raw cow milk, sheep milk, and goat milk samples were collected from the University farm from April to May, 2018. Goats and sheep (breeds) involved in this study are Red Maradi and Yankasa. The sampling was carried out during the dry season. Details of the samples collected and types of breeds have appeared in Table 1. Each milk sample of $200 \mathrm{~mL}$, were collected by hand expression into glass tubes following accumulation, was moved under the sterile condition to the science exploration research laboratory in the icebox at a temperature of about $4{ }^{\circ} \mathrm{C}$ and where then stored at $-20^{\circ} \mathrm{C}$ until examination.

Table 2: Milk samples material under study

\begin{tabular}{lll}
\hline Sample category & Breeds & Milk samples \\
\hline Cow & F1 & 30 \\
Goat & Red maradi & 20 \\
Sheep & Yankasa & 16 \\
Total & 3 & 66 \\
\hline
\end{tabular}


Table 3: Temperature, rainfall and humidity from January-December (2018) in Damaturu Yobe State

\begin{tabular}{|c|c|c|c|}
\hline Months & Temperature $(\max / \mathrm{min})$ & Humidity (out/in) $\%$ & rainfall $(\mathrm{mm})$ \\
\hline January & $30.1 / 29.2$ & $26 / 27$ & 0.0 \\
\hline Feb & $30.9 / 30.2$ & $20 / 22$ & 0.0 \\
\hline March & $32 / 31.3$ & $10 / 11$ & 0.0 \\
\hline April & $33.2 / 32.7$ & $11 / 12$ & 2.1 \\
\hline May & $34.2 / 34.1$ & $41 / 37$ & 86.5 \\
\hline June & $35.8 / 34.8$ & $56 / 152$ & 121.5 \\
\hline July & $36.9 / 35.3$ & $78 / 69$ & 99.7 \\
\hline August & $30.9 / 30.1$ & $80 / 71$ & 99.7 \\
\hline September & $33.9 / 31.7$ & $76 / 62$ & 122.7 \\
\hline October & $30.9 / 31.7$ & $57 / 44$ & 0.0 \\
\hline November & $30 / 30.1$ & $32 / 30$ & 0.0 \\
\hline December & $29.2 / 27.4$ & $21 / 23$ & 0.00 \\
\hline
\end{tabular}

Source: Desert Research, Monitoring and Control Centre 2018

\section{Determination of Aflatoxin M1 by HPLC}

The strategy utilized for assurance of AFM1 was the AOAC Official Method (AOAC 2010).

Preparation of milk sample for high performance liquid chromatography (HPLC)

After warming the milk sample at around $37^{\circ} \mathrm{C}$ in the water bath, the liquid milk was then centrifuged at $2000 \mathrm{rpm}$ for $15 \mathrm{~min}$ to separate the fat layer and then filtered through a glass microfibre filter paper (Whatman Schleider \& Schuell, Maidstone, England, product number 934-AH). Later, $20 \mathrm{ml}$ of filtered extract was transferred to a $50 \mathrm{ml}$ capacity vial and $20 \mathrm{ml}$ of sodium acetate buffer (pH 5.0) was added. The $\mathrm{pH}$ of the mixture was measured and corrected to 5.0 using an appropriate volume of a $0.1 \mathrm{M}$ glacial acetic acid solution. The mixture was directly passed through an immunoaffinity column (Neocolumn, Neogem Europe, UK) at a flow rate of approximately $1.0-1.5 \mathrm{ml} \mathrm{min}^{-1}$. After adding the mixture the column was washed with $40 \mathrm{ml}$ of ultrapure water (Milli Q, Millipore, and Bedford, MA, USA). The column was dried by applying positive pressure with a syringe and bound AFM1 was eluted with $2.0 \mathrm{ml}$ of HPLC-methanol which was recovered in a 4 $\mathrm{ml}$ vial previously treated with acid. The eluate was evaporated under nitrogen gas and reconstituted with $500 \mu \mathrm{l}$ of the mobile phase before liquid chromatography analysis.
The Detection and quantification of sample extracts were performed by high-performance-liquid chromatography (HPLC) with a liquid chromatography system equipped with a LC-10AT Shimadzu pump (Kyoto, Japan), a Shimadzu RF-10AXL fluorescence detector (excitation $365 \mathrm{~nm}$ and emission $435 \mathrm{~nm}$ ), an injection volume of $100 \mu 1$, and a reverse phase column $(250-4.6 \mathrm{~mm}$, particle size of 3 $\mu \mathrm{m}$ ) and pre column (Synergi Fusion, Phenomenex Inc., Torrance,CA, USA) kept at room temperature. The mobile phase consisted of an isocratic mixture of water and acetonitrile at a volume ratio of 75:25 and a flow rate of $1.0 \mathrm{ml} \mathrm{min} \mathrm{m}^{-1}$. A calibration curve was prepared using standard AFM1 solutions in mobile phase at concentrations of $0.05,0.01,0.02$, and $0.03 \mathrm{ng} \mathrm{ml}^{-1}$. The standard obtained (Sigma, St. Louis, MO, USA, and product code 6428, 10 lg) as purified crystalline AFM1 was dissolved in HPLC-grade acetonitrite and its concentration was determined by spectrophotometer according to Trucksess (2009).

\section{Analytical performances}

The Limit of detection (LOD) for AFM1 was assessed as $10 \mathrm{ng} / \mathrm{ml}$ and Limit of quantification (LOQ) was $50 \mathrm{ng} / \mathrm{ml}$ respectively, the linearity of the curve was 10 to $50 \mathrm{ng} / \mathrm{ml}$. The calibration curve for $\mathrm{AF}$ M1 had a linear equation of $\mathrm{y}=4147.142 \mathrm{x}-230.3028$; Figure 1 gives the correlation coefficient of $\mathrm{R}^{2}=0.993$ and retention of 10 $\min$. 


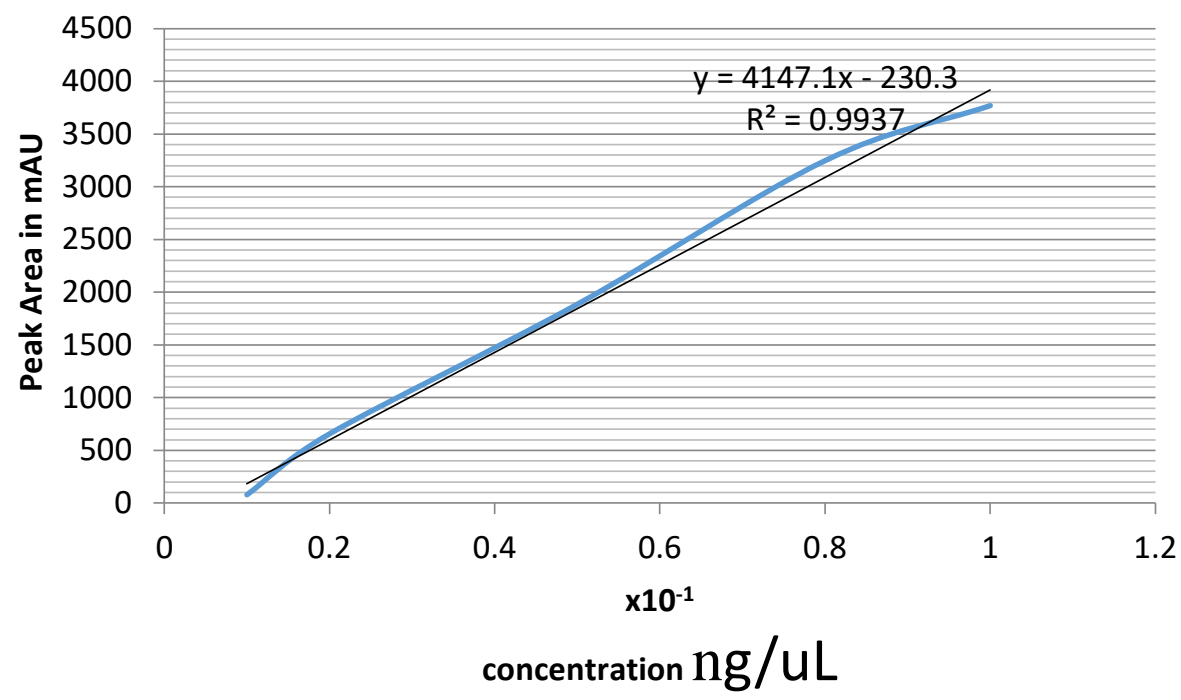

Figure 1: gives calibration curve of AFM1 with correlation coefficient

Human hazard appraisal to presentation to add up to aflatoxins utilizing the utilization of milk.

\section{Dietary admission assessment}

The estimate dietary intake of AFM1 was estimated following the technique for Hung et al (2016). The consumption of different milk by individual per day, was estimated based on a food frequency questionnaire by European Food Safety Authority (EFSA) guidelines on information for national food consumption, direct interviews has been made, $(\mathrm{n}=116)$ including 116 individuals (table 4 ), asking them what type of milk do they consume per day and the quantity they devoured.

Table 4: Daily intakes of various milk produce in YUF and Demographic profile of participant samples

\begin{tabular}{lllr}
\hline Milk category & $\begin{array}{l}\text { Daily intake } \\
(\text { Kg/person/day })\end{array}$ & \multicolumn{2}{c}{ Demographic characteristic } \\
& 0.375 & $47(40.51)$ & $69(59.48)$ \\
Cow milk & 0.000 & $0(0.00)$ & $0(0.00)$ \\
Sheep milk & 0.000 & $0(0.00)$ & $0(0.00)$ \\
Goat milk & & &
\end{tabular}

\section{Exposure estimation}

Calculation of the Estimated Daily Intake (EDI) was done by using the mean levels of aflatoxins obtained in cow, goat and sheep milk samples, and the daily intakes of each sample and the average body weight were recorded. The EDI for mean aflatoxins was calculated according to the following formula and expressed in $\mu \mathrm{g} / \mathrm{kg}$ of bodyweight/day ( $\mu \mathrm{g} / \mathrm{kg}$ b.w/day). (Taghizadeh et al., 2018).

\section{$\mathrm{EDI}=\quad$ daily intake of milk $X$ mean level of AFM1 Average body weight $(\mathrm{kg})$}

\section{Estimation of Hazard index (HI)}

The Hazard Index (HI) was calculated according to the belowmentioned formula, by dividing the EDI by TD50, divided by the safety factor of 50,000 . TD50 is the dose (ng/kg/body/weight/day) required to induce tumors in half of the test animals that would have remained tumor-free at zero doses as described by Ismail et al (2016).

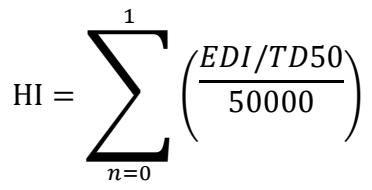

Analytical Package (Software)

Analysis of the data generated was performed using SPSS version 24 . The generated data was analyzed using simple linear correlation to evaluate the relationship between AFM1 concentrations. The pvalue of $<0.05$ was considered statistically significant.

\section{RESULTS}

Table 4 shows the occurrence of AFM1 in the milk samples collected (30 cow milk, 20 goat milk, and 16 sheep milk respectively, $36(54.54 \%)$ of the 66 samples were found to be contaminated with AFM1. The contaminated rate of AFM1 in diary milk of cow, goat and sheep was found to be $80 \%, 25 \%$, and $43.75 \%$ respectively.

The range of AFM1 level in the milk samples was found to be 
between 0.01 and $0.18 \mu \mathrm{g} / \mathrm{l}$. The range of AFM1 level in milk samples from cow, goat, and sheep was 0.03-0.81 $\mu \mathrm{g} / 1,0.01$ $0.07 \mu \mathrm{g} / \mathrm{l}$ and $0.03-0.08 \mu \mathrm{g} / \mathrm{l}$. $54.54 \%$ of the contaminated samples had AFM1 level exceeding the limit $(0.05 \mu \mathrm{g} / \mathrm{l})$ set by the European Commission. The highest concentration AFM1 was found cow (F1) with tale code $063(0.81 \mu \mathrm{g} / \mathrm{l}$, sixteen times higher than the European Union maximum level. This is to note that the concentration at $0.81 \mu \mathrm{g} / 1$ was higher than the value set by US food and drug administration. About 6 samples of cow milk had concentration $(0.05 \mu \mathrm{g} / \mathrm{l}>)$ with values between $0.03-0.04 \mu \mathrm{g} / \mathrm{l}$.

Goats and sheep had concentration below $0.05 \mu \mathrm{g} / 1$ at $75 \%(15$ samples) and 56.25 (9 samples) with levels of AFM1 ranging from $0.01-0.04 \mu \mathrm{g} / 1$ and $0.03-0.04 \mu \mathrm{g} / 1$ respectively.

There is no significant difference in AFM1 means concentration found between the cow milk, goats milk and sheep milk samples ( $p$ $=0.3624)$, most of cow milk samples had concentration higher than the limit imposed by EC Reg. 1881/2006.

Table 5: Occurrence of AFM1

\begin{tabular}{llll}
\hline (Milk Category) & No of samples & Incidence of AFM1 $(\%)$ & Range of AFM1 $(\mu \mathrm{g} / \mathrm{L})$ \\
\hline Cow & 30 & $24(80)$ & $0.03-0.81$ \\
Goats & 20 & $5(25)$ & $0.01-0.07$ \\
Sheep & 16 & $7(43.75)$ & $0.03-0.08$ \\
Total & 66 & $36(54.54)$ & $0.01-0.81$ \\
\hline
\end{tabular}

Table 6: Estimated daily intake (EDI) and Hazard indices of Aflatoxin $M_{1}$ via consumption of milk from different animal species at Yobe State University Farm

\begin{tabular}{|c|c|c|c|c|c|}
\hline (Milk Category) & $\begin{array}{l}\text { Mean total } \\
\text { Aflatoxin }(\mu \mathrm{g} / \mathrm{L})\end{array}$ & Age (yrs) & Average body weight $(\mathrm{kg})$ & $\mathrm{EDI}(\mu \mathrm{g} / \mathrm{Kg}$. bw/day $)$ & $\mathrm{HI}$ \\
\hline Cow milk & 0.1333 & $17-65$ & $63.15^{\mathrm{a}}$ & 0.00158 & $1.58 \times 10$ \\
\hline Sheep milk & 0.0519 & NS & NS & NS & NS \\
\hline Goat milk & 0.0462 & NS & NS & NS & NS \\
\hline
\end{tabular}

Key: $\quad E D I$ estimate daily intake $\quad H I$ hazard index $\quad N S$ not significant (not consumed)

$\mathrm{TD}_{50}=0.2 \mathrm{ng} / \mathrm{Kg}$. bw (Kuiper-Goodman, 1990)

lng $=0.001 \mu \mathrm{g}$

$\mathrm{A}=$ Average body weight of an adult in Nigeria (Akinpelu et al., 2015)

Average Daily Intake $(\mathrm{Kg} /$ person/day $)=0.75$

\section{DISCUSSION}

The findings revealed a high occurrence of AFM1 sullying in the samples examined, and a high level of positive tests with AFM1 level surpassing the level of $0.05 \mu \mathrm{g} / 1.54 .54 \%$ of samples indicated discernible degrees of toxin $(>0.05 \mu \mathrm{g} / \mathrm{l})$; most of the positive samples were estimated to contains AFM1 between $0.06 \mu \mathrm{g} / 1$ and $0.19 \mu \mathrm{g} / 1$ with the exception of raw milk from cow milk which is above $(>0.80 \mu \mathrm{g} / \mathrm{l})$. Milk samples obtained from Sheep and Goats showed concentration between $(0.03-0.04 \mu \mathrm{g} / \mathrm{l}) 56.25 \%$ and $(0.01-$ $0.04 \mu \mathrm{g} / \mathrm{l}) 75 \%$ lower $(<0.05 \mu \mathrm{g} / \mathrm{l})$ AFM1 content. Similar study by Cammilleri et al. (2018) in southern Italy recorded the low level of the toxin (just two) samples at $6 \%$, (sheep milk) that slightly exceeded the EU maximum levels of $0.05 \mu \mathrm{g} / \mathrm{l}$, He further asserted that the low degree of the toxin recorded in his study maybe be due to the high amount of proteins and their affinity with AFM1. The low level of the toxin in the goat and sheep milk in this study is accordance with other studies that reported that local breeds may have more resistance to aflatoxin (Malissiova et al., 2013). This outcome additionally, conforms with the outcome of similar research reported by (Hussain et al., 2010; Fallah et al., 2011) that goat milk is less contaminated than cow milk, and this is a result of the distinctive stomach related contraption and mechanism of AFB1 assimilation of animals, or the diverse feeding proportion utilized in cows breeding contrasted with ovine and caprine species.

These findings are in contrast to that recently obtained by Okeke et al. (2012) which indicated sullying of dairy cattle milk samples with AFM1 in the northern part of Nigeria (Bida) at mean concentration of $(0.575-0.924 \mu \mathrm{g} / \mathrm{l})$ with about $100 \%$ prevalence surpassing the standard level of $0.05 \mu \mathrm{g} / 1$ for diary milk and other milk product. AFM1 has been found in most dairy items with a high fixation slope than the worthy furthest reaches of detection $(>0.05 \mu \mathrm{g} / \mathrm{l})$ in Nigeria (Makun et al., 2009, Okeke et al., 2012). The findings by these researchers with an abnormal state of the toxin in milk and milk products maybe because of the administrative body (National Agency for Food and Drug Administration and Control) in Nigeria with poor regulatory enforcement on the nature of feeds. Hence, the state of poor enforcement and sanctions has left most projects unchecked. Raw milk sample of dairy animals had $80 \%$ with mean AFM1 concentration of $0.1333 \mu \mathrm{g} / 1$ levels which is unsafe for 
drinking. These cows are generally kept inside bound munching territory and some of the time nourished utilizing biomass of harvests (sorghum, maize, millets, and groundnut) put away at the ranch house, it means that these bovines were presented to the abnormal state of AFB1 in their feeds which is processed to aflatoxin M1 and discharged into milk. Sassahara et al. (2005) revealed that that the measure of AFB1 ingested by cows and the amount of AFM1 discharged in milk is generally 0.2 to $4 \%$. Han et al (2013) in their overview of AFM1 in crude milk produce in china recorded just three samples containing AFM1 at the level surpassing the EU lawful point of confinement. High sullied tests with AFM1 discovered during this overview might be because of regular variety in AFM1 contamination in milk, bovine gets increasingly concentrated feed in the dry season. Tajkarimi et al. (2008), saw that the period of production is significant in deciding AFM1 in cheese and showed that milk used to produced cheese in winter is contaminated than those produced in summer. In this work, cow milk, sheep milk, and goat milk samples were collected in dry season, then animals were fed using stored composite feeds. With this, we expect that the animals were nourished with feeds contaminated with AFB1 and subsequently, produced milk with high level of AFM1 in the samples analyzed. Another investigation in Italy on cheese samples produced with milk from dairies during summer showed that cheese has less contamination of AFM1(Anfosi et al., 2011); cheese belongs to milk from grazing animals which has lesser defilement than that during winter and spring which have a place with animals fed with composite and stored fodder.

This study is in line with the data reported in Morocco by Zinedine et al. (2006) that AFM1 in pasteurized milk from dairies had contamination levels ranging from $0.001-0.117 \mu \mathrm{g} / 1$.

The estimated intake of AFM1 from consumption of cow milk products by the teachers and the students was $0.00158 \mathrm{ug} / \mathrm{kg} . \mathrm{bw} / \mathrm{day}$ based on one-day recall methods, while the hazard index was 1.58 $\mathrm{x} 10^{-4}$. According to Cano- Sancho et al. (2013) estimated the exposure of the adult Catalonian population (20 to 65 years old) to be $0.039 \mathrm{ng} \mathrm{kg}^{-1} \mathrm{BW}$ day ${ }^{-1}$. The mean milk intake was $305 \mathrm{~mL}$ day1 (750 mL day-1 for 95th percentile). Early estimation of AFM1 intake performed in 2001 by the joint FAO/WHO expert committee on food additives (JECFA) was calculated to be $6.8 \mathrm{ng}$ per person per day (approximately $0.11 \mathrm{ng} \mathrm{kg}^{-1} \mathrm{BW}$ day-1) for the European type diet (2001).

\section{CONCLUSION}

The seasonal variation ought to be assessed in Nigeria as it influences AFM1 formation in milk, on the presumption that animals fed on pasture have less exposure to AFB1 ingestion and therefore less AFM1 contamination in milk. Studies based on local and exotic breeds need to be done with the speculation that local breeds may have more prominent protection from aflatoxin, given that no accessibility of such research discoveries in Nigeria. Moreover, the Nigerian administrative body (NAFDAC) should carefully force control on the animal feeds which consequently decreases the odds of aflatoxin in milk and milk products of ruminant animals.

\section{REFERENCE.}

A. O. A. C (2010). Official Methods of Analysis of Chemistry, Washington, D.C. Association of Official Analytical Chemists (18th Ed.).

Akinpelu A. O, Oyewole O. O and Adekanla BA. (2015). Body size perceptions and weight status of adults in a Nigerian Rural Community. Ann Med Health Sci Res; 5:358-64

Anfosi L., Baggiani C, Giovannoli C and Giraudi G. (2011). The occurrence of Aflatoxin M1 in Dairy Products Italy. Anal. Bional. Chem

Bellio A., Bianchi D., Gramaglia M., Loria A., Nucera D., Gallina S., Gill M. and Decastleli L. (2016). Aflatoxin M1 in cow's milk: Method validation for milk sampled in Northern Italy. Toxins, 857.

Caloni F., Stammati A., Frigge G., De Angelis. I (2006). Aflatoxin M1 absorption and cytotoxicity on human intestinal in vitro model. Toxin 47, 409-415

Camilleri G., Graci S. and Collura, R. (2018). Aflatoxin M1 in cow, sheep, and donkey milk produced in Sicily, Southern Italy. Mycotoxin Res 35, 47-53

Cano-Sancho, G., Sanchis, V., Marín, S. and Ramos, A.J. (2013). Occurrence and exposure assessment of aflatoxins in is (Spain). Food Chem. Toxicol. 51, 188-193. is[ip?

Dutton M.F, Mwanza M, de Kock S and Khilosia LD. (2012). Mycotoxins in South African foods: a case study on aflatoxin M1 in milk. Mycotoxin Research; 28: 17-23.

EFSA (2009). General principles for the collection of National food consumption data in the view of pan-European dietary surveys.

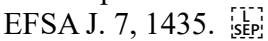

Elzupir A.O and Elhussein A. M. (2010). Determination of aflatoxin M1 in dairy cattle milk in Khartoum State, Sudan. Food Control; 21: $945-946$

Fallah A. A., Rahnama M., Jafari T. and Saei-Dehkordi S. S. (2011). Seasonal variation of aflatoxin M1 contamination in industrial and traditional Iranian dairy products. Food Control 22 1653-1656.

Gallo A., Solfrizzo M., Epifani F., Panzarini G., Perrone G. (2016). Effect of temperature and water activity on gene expression and aflatoxin biosynthesis in Apergillus flavus on almond medium. Int J. food Microbial. 217 162-169. 10.1016/j.ijfoodmicro.2015.10.

Henry S. H, Whitaker T, Rabbani I, Bowers J, Park D, Price W, and Bosch F. X. (2001). Aflatoxin M1. Joint FAO/WHO Expert Committee on Food Additives (JECFA); 47

Hussain, Z., Khan, M.Z., Khan, A., Javed, I., Saleemi, M.K., Mahmood, S. and Asi, M.R. (2010). Residues of aflatoxin B1 in broiler meat: Effect of age and dietary aflatoxin B1 levels Food and Chemical Toxicology 48 (12): 3304-3307

Hussain, Imtiaz, and Institue of chemistry (2009). "Micro-Analysis of Aflatoxin M 1 in dairy products at trace levels and its elimination."

International Agency for Research on Cancer (IARC) (2011). Monographs on the evaluation isperion the carcinogenic risk of chemicals to man, 40, 83, sIn INCHEM

Ismail A., M. Riaz, R.E. L., Akhtar S., Gong Y.Y., and Hameed A. (2016). Seasonal prevalence level of aflatoxin M1 and its Estimated 
Daily intake in Pakistan, Food Control 60 461-465

JECFA (2001). Safety evaluation of certain mycotoxins in food. Fifty-sixth meeting of the Joint FAO/WHO Expert isperichmittee on food additives. In FAO Food Nutric Paper; FAO: Rome, Italy.

Joint FAO/WHO Expert Committee on Food Additives (2001). "Safety evaluation of certain mycotoxins in food," in 56th meeting of the JECFA-FAO Food and Nutrition Paper 74/WHO Food Additives Series 47, Geneva

Malissiova E., Tsakalof A., Arvanitoyannis I. S., Katsaflaka A., Katsioulis A., Tserkezou P., Koureas M, G. Govaris A. and Hadjichristodoulou C. (2013). Monitoring aflatoxin M1 levels in ewes and goats milk in Thessaly, Greece; Potential risk factors under organic and conventional production Schemes. Food Control 34: $241-248$.

Malka B., Shmulik F., Joshua M., Ran S., Olga C., Jakob A.S., Stefan S., Rina A., Sima A. and Alan S.T. (2013). Carry-over of Aflatoxin B1 to Aflatoxin M1 in High Yielding Isreali Cows in Midand Late-lactation 5, 173-183; doi: 10.3390

Martins, M. L., Martins, H. M. and Bernardo, F. (2001). Aflatoxins in spices marketed in Portugal. Food additives and contaminants 18 (4), 315-319.

Makun H. A., Gbodi T. A, Akanya H. O, Salako E. A. and Ogbadu G. H, (2009). Fungi and some mycotoxins found in moldy sorghum in Niger State, Nigeria. World J. Agric; 5(1): 5-17

Motawee M. M., Bauer J., and McMahon D. J. (2009). Survey of Aflatoxin M1 in Cow, Goat, Buffalo and Camel Milks in IsmailiaEgypt. Bull Environ Contam Toxicology; 83: 766-769

Mulunda, M., Lubanza N., Mathew N., Lebohang M. and Frank B. (2013). "A Decade of Aflatoxin M 1 Surveillance in Milk and Dairy Products in Developing Countries ( 2001-2011 ): A Review."

Okeke K. S, Abdullahi I. O, Makun H. A. and Mailafiya S. C, (2012). A Preliminary Survey of Aflatoxin M1 in dairy cattle products in Bida, Niger State, Nigeria. Afri. J. Food Sci. Tech vol 3(10) pp 273-276.

R.W. Han, N. Zheng, J.Q. Wang, Y.P. Zhen, X.M. Xu, S.L. Li (2013). Survey of aflatoxin in dairy cow feed and raw milk in China, Food Control 34 pp 35-39

Taghizadeh S.F., Rezaee R., Davararynejad G., Asili J., Nemati S.H., Goumenou M., Tsakiris I., Tsatsakis A.M., Shirani K. G. K. (2018). Risk assessment of exposure to aflatoxin B1 and ochratoxin A through consumption of different Pistachio (Pistacia vera L) cultivars collected from four geographical regions of Iran, Environmental Toxicology and Pharmacology; 61: 61-66.
Sarimehmetoglu, B., Kuplulu, O. and Celik, T. H. (2004). Detection of aflatoxin M1 in cheese samples by ELISA. Food Control, 15, 4549.

Sasahara M. Netto P. D and Yanaka E. K (2005). Aflatoxin occurrence in foodstuff supplied to dairy cattle and aflatoxin M1 in raw milk in the North of Paraa state. Food Chemistry and Toxicology; 43: 981-984.

Schmidt-Heydt M., Rufer C.E., Abdel-Hadi A., Manga N., Geisen R. (2010). The production of aflatoxin B1 or G1 by Aspergillus paraciticus at various combination of temperature and water activity is related to the ratio of aflS or aflR expression. Mycotoxin Res. 26 241-246. 10.1007/s12550-010-0062-7

Substances: Food Items and Constituents, Heterocyclicaromatic Amines and Mycotoxins. In:

IARC monographs on the evaluation of carcinogenic risks to humans. pp. 245-395, International Agency for Research on Cancer, ISBN 928321256-8, Lyon, France

Kuiper-Goodman T. (1990). Uncertainties in the risk assessment of three mycotoxins: Aflatoxin, ochratoxin, and zearalenone Can. J. Physiol. Pharmacol. 68: 1017-1024.

Tajkarimi M., Aliabadi-Sh F., Nejad A. S., Poursoltani H., Motallebi A. A., and Mahdavi H. (2008). Aflatoxin M1 contamination in winter and summer milk in 14 states in Iran, Food Control, vol 19, no. 11, pp, 1033-1036

Trucksess M.W., Whitaker T.B., Weaver C.M., Slate A., Giesbrecht F.G., Rader J.I., Betz J.M., USDA ARS. (2009). Sampling and analytical variability associated with the determination of total aflatoxins and ochratoxin $\mathrm{A}$ in powdered ginger sold as a dietary supplement in capsules. J Agric Food Chem 57(2): 321- 5

Wagacha J. M. and Muthomi J. W. (2008). Mycotoxin problem in Africa's current status implications food safety and health and possible management strategies. International Journal of Food Microbiology; 124:1-12.

Whitlow W. M, Hagler J. R and Diaz (2010). Mycotoxins in feeds. Quality feed Mycotoxins. Feedstuff. Feedstuffs 83,

Zinedine A., Brera C., Elakhdari S., Catano C., Debegnach F., Angelini S., De Santis B. F. M., Benlemlih M., Minardi V. and Miraglia M. (2006). Natural occurrence of mycotoxins in cereals and spices commercialized in Morocco. Food Control; 17: 868-874.

(C)2020 This is an Open Access article distributed under the terms of the Creative Commons Attribution 4.0 International license viewed via https://creativecommons.org/licenses/by/4.0/ which permits unrestricted use, distribution, and reproduction in any medium, provided the original work is cited appropriately. 